\title{
A Move from Data-Based Towards Analysis-Based E- Administration System in Higher Education
}

\author{
Ching-Dar Lin, Min-Jin Lin, and Yen-Hui Liang
}

\begin{abstract}
Applying information technology to facilitate administrative tasks in higher education has been done for a long time. At the early stage, e-administration was PC-based and spread over different offices, and each office had to build its own database. Later on, e-administration evolved as a webbased administration (abbreviated as WBA hereafter) that was done by integrated computer systems so that different offices can share common databases. Both PC-based and web-based administration system are database-driven with an aim to save labor, cost and time. The aim of this paper is to investigate the possibility of advancing the current WBA further to support the administrators' decision making in higher education. We took a case study approach to analyze the current tasks accomplished by the WBA in a private university in the eastern part of Taiwan, and we investigated its implementation, advantages and problems. Then, we used prototyping method to illustrate an analysis-based e-administration system to support the Dean of Office of Academic Affair (abbreviated as DOAA) in decision making. The result of this study is a primitive analysis-based e-administration system design regarding to Office of Academic Affairs that provided the critical information for DOAA to recognize and rectify problems. The long-term enrollment rate, teaching evaluation, failure rate, registration rate, dropout rate, and graduation rate among five departments in a popular college shown in the graph format over six years help the DOAA see the trends, the signal of problems, and help him/her to make better decisions.
\end{abstract}

Index Terms - data-based e-administration, analysis-based e-administration, tactic knowledge, university administrator, decision making.

\section{INTRODUCTION}

Using computers to handle administrative tasks in higher education started at least twenty years ago in Taiwan. Initially, the computerization of administrative tasks was done in PC at each office where the database was discrete and can not be shared among different offices. Therefore, students', teachers' or staff' databases were key-in over and over again among different offices. Upon the introduction of the world-wide-web in 1990, the web-based administration

Manuscript received June 14, 2011; revised July 6, 2011.

This work is an independent research without funding from governmental or private agencies.

Ching-Dar Lin is with the Office of Academic Affairs and a Professor of Graduate Institute of Education, Tzu-Chi University, Hualien, Taiwan. (Email: abcd1812@mail.tcu.edu.tw).

Min-Jin Lin is with the Department of Curriculum Design and Human Potential Development, National Dong-Hwa University, Hualien, Taiwan (corresponding author, Phone: 886-3-8227106 ext. 1856, Fax: 886-38237283,E-mail:mjhl@mail.ndhu.edu.tw).

Yen-Hui Liang is with the Office of Academic Affairs, Tzu-Chi University, Hualien, Taiwan. (E-mail: yhliang@mail.tcu.edu.tw). (abbreviated as WBA in this paper) became more and more popular in Taiwan in the past ten years. Many universities set up the WBA system for faculty and staff to input data and others can access the information through Internet. At this time, the WBA systems are integrated, and the databases are shared among different offices.

The purposes of e-administration in universities were to reduce labor, cost and time for repetitive tasks, to promote the administrative efficiency, and to promote the quality of university management [1]. WBA greatly reduced the repetitive tasks, labor and cost. However, did WBA really promote the efficiency and quality of administrative tasks? A survey of five universities showed varied results [1]. As far as needs of university administrators are concerned, did the current WBA system help them get the essential information to promote the administrative efficiency and make better decisions? Thess question remained unanswered.

This study took a case study to describe the tasks accomplished by current WBA system and its implementation, advantages and problems in a private university in the eastern part of Taiwan. Then, we pointed out the needs of the administrators in seven offices in the case university and investigated the possibility of advancing the current WBA to fulfill their needs. We used an example regarding to the Office of Academic Affairs to explore a direction of evolving from data-based WBA towards a new e-administration system to provide the necessary analysis for the DOAA to get critical information for better decision making and take necessary actions to solve problems.

\section{TASKS ACCOMPlished By WBA Sytem In THE CASE UNIVERSITY}

Information technology plays a central role in transforming higher education by offering unimaginable opportunities and demanding unforeseen responses [2]. We took a case study approach to illustrate how the IT professionals endeavored to help a private university located in the eastern part of Taiwan to achieve the current status of WBA. We discussed about the tasks accomplished by WBA as follows.

\section{A. Office of Academic Affairs}

The WBA system for the Office of Academic Affairs handled students' recruitment, registration, course selection, grade recording, and graduation eligibility evaluation. It also took care of teachers' course offering, teaching hours filling, and assessment.

\section{B. Office of Student Affairs}

The WBA system for the Office of Student Affairs handled tasks regarding to management of students' counseling, accommodation, extra-curricular activities, and student loan. It also covered management of various types of 
school privileges, information filling of overseas alumni, military service and school security services.

\section{Office of General Affairs}

The WBA system for the Office of General Affairs handled procurement, custody of properties, inventory claim, construction and maintenance. It looked after management of campus parking, campus guest house accommodation, on duty campus guard, school space usage, and dispatching of official car. It also covered the receiving and signing of official documents, query of telephone extension, management of tuition, miscellaneous fees, and meal vouches.

\section{Office of Accounting}

The WBA system for Office of Accounting handled tasks regarding to annual planning / budgeting, applications for miscellaneous charges, work-study payment, petty cash, and teachers' hourly fee of extra teaching.

\section{E. Personnel Office}

The WBA system for Personnel Office handled tasks regarding to payroll, personnel database management, recruitment of faculty and staff, leave management, personnel performance appraisal, gift distribution on three main holidays, on-line application for in-service training.

\section{F. Secretariat Office}

The WBA system for Secretariat Office handled tasks regarding to on-line signature and approval of the official documents, on-line application for using university seals, and school news distribution through on-line bulletin.

\section{G. Office of research and development}

The WBA system for Office of Research and Development handled tasks regarding to application and evaluation of research proposals on campus, management of database of teachers' research results, and teachers' expertise and special performance.

\section{IMPLEMENTATION, AdVANTAGES AND PROBLEMS OF CURRENT WBA SYSTEM}

\section{A. Considerations Before Implementing WBA}

- Successful WBA requires sufficient hardware, stable campus network, basic computer competence of the users, and a firm support from school administrators.

- Successful WBA depends on reasonable administrative procedures. Immature administrative operations may not be suitable to convert into WBA system.

- WBA is not equal to the promotion of working efficiency or promotion of service quality. Moreover, some administrative tasks that were diverse or changeful may require more human intervention. Therefore, they may not be easy to convert into WBA system.

- WBA requires users to change their habits of operation, but people were often against something that was unfamiliar to them. How to conquer the resistance of users (including faculty, students and staff) remained a big issue.

- Sufficient safety control of network is critical. Otherwise, the important or confidential information may be leaked out, modified or destroyed.

- Face-to-face communication is often reduced significantly after WBA system was implemented.

- Alternatives must be established in case computers or network was out of orders.

- WBA is not a guarantee of administrative efficiency or service quality.

\section{B. Advices for Successful Implementation of WBA}

Advices from the third author (an IT professional in the case university) for successful implementation of WBA were listed as follows:

- The establishment of standard operation procedure (SOP) is the key of success for WBA.

- Control of cost efficiency is crucial. Money, human resource, and time must be spent opportunely.

- It is important to evaluate if the hardware and software are sufficient before implementing WBA on campus.

- The concepts of computer and network security among faculty, students and staff must be promoted.

\section{Priorities of Implementing WBA}

The contents and implementation of WBA varied among different universities depends on the criteria or priorities set for implementation. In the case university, the priorities of implementation were set as follows:

- Basic database went first. The establishment of database of student, faculty and staff got highest priorities in implementation of WBA system.

- Critical tasks that were related to more users got higher priority. For examples, students' course selection system, student grade calculation and recording system, faculty and staff's leave system, and payroll system were on the top priorities.

- Tasks that need to be audited and tracked (such as official documents handling system and budget auditing system) got higher priority.

- Internal management or on-going tasks also got higher priority.

\section{Advantages of $W B A$}

The advantages of implementing WBA were stated as follows:

- Avoiding repetitive tasks among different offices,

- Saving labor, cost and time.

- Reducing human errors.

- Reducing consumption of papers (with a goal to move the university toward a paperless office).

- Providing just-in-time access of information.

- Reusing information.

- Using cloud computing and setting up mobile office.

\section{E. Problems of Current WBA}

The current WBA in the case university reduced quite a lot of time, labor, and cost. It cut down the tedious and repetitive tasks for the staff and fulfilled many needs of students and faculty. It is a great achievement considering the limited numbers of the IT professionals on the computer center in the case university. However, it seemed that the current WBA do not provide enough supports for university administrators in the seven offices mentioned earlier to 
make decisions. Firstly, IT professionals in the computer center may not know exactly what information is critical for university administrators in the seven offices in terms of decision making. Secondly, the original purpose to implement e-administration system in early stage for the case university was to convert various application forms that were originally in paper format into electronic format, and thus faulty, students and staff can apply for them on line. The IT professionals looked after the needs of students, faculty and staff, but not at the level of the university administrators yet.

Due to the current status of WBA system, the information needed by the university administrators to make decisions was often generated by staff in each office by pulling data from the database of the WBA system. They made tables or graphs by using software (such as Microsoft Word, Excel, etc) and then printed them out. Those tasks were usually done semi-manually for the university administrators to interpret the tables and graphs provided by the administrative staff. And then, the administrators would try to get a whole picture or try to solve problems based on the information provided.

Some of the difficulties were due to the fact that in many cases the knowledge embedded in the university administrators heads were tactic knowledge. In the field of knowledge management, the concept of tacit knowledge refers to a knowledge possessed only by an individual and difficult to communicate to others via words and symbols (http://en.wikipedia.org/wiki/Tacit_knowledge). Therefore, tactic knowledge was usually hard to write down or codify to be computer programs.

\section{INFORMATION NEEDED FOR UNIVERSITY ADMINISTRATORS TO MAKE DECISION}

\section{A. Dean of the Office of Academic Affairs}

The Dean of the Office of Academic Affairs (abbreviated as DOAA) may concern most about how many students applied, admitted and registered in all departments. DOAA may also care about the registration rate, the suspension rate, the withdrawal rate, and the causes for suspension and withdrawal. These issues are important because the Ministry of Education in Taiwan will reduce the numbers of students admitted to a department if its registration rate is too low. The DOAA may also care about students' failure rate in certain courses because the numbers of remaining students will influence the tuition income of the university. Under limited budget, the DOAA also concerns about the teaching evaluation of the faculty, and courses offered by faculty to see if they meet the education objectives defined by school or departments.

\section{B. Dean of Office of Student Affairs}

The Dean of office of student affairs (abbreviated as DOSA) cares about students' well-beings. The DOSA may want to know which and how many students are in risk (e.g. emotional distress, possibilities of committing suicides etc) and who are in need of counseling or medical treatment. How many students encountered car or motorcycle accidents or death? The DOSA may want to know how many students live off-campus, and are the living places safe for them? The DOSA may also care about the special merit or award some students had in academic or other fields. DOSA may concern about the connection of the alumni and the actions taken to motivate the alumni to make generous donation.

\section{Dean of Office of General Affairs}

The Dean of Office of General Affairs (abbreviated as DOGA) cares about the facility and environment of the university such as status of school buildings (construction and maintenance), properties, equipment, and utility usage etc. DOGA also wants to make sure that the campus environment is safe, clean and comfortable for faculty, students and staff to stay.

\section{Director of Accounting Office}

The Director of Accounting Office (abbreviated as DAO) cares most about how to find money or funding to make proper budget for the next fiscal year and make the proper arrangement with the university administrators to decide the ratio of funding for different offices and departments. The DAO would want to make sure that the items purchased by each faculty, staff, department or office fall into the right categories. The DAO may also care about spending of funding or budget meets the percentage and deadline set by government or funding agencies each fiscal year.

\section{E. Director of Personnel Office}

The Director of Personnel Office (abbreviated as DPO) cares about updating and execution of laws and regulations regarding to benefits and privileges (such as proper payment, sick leave, holidays, promotion, retirement, appealing etc) of faculty and staff. The DPO also cares about solving problems or resolving conflicts among faculty or staff.

\section{F. Director of Secretariat Office}

The Director of Secretariat Office (abbreviated as DSO) is a coordinator and facilitator among different offices. DSO cares most of the proper operations and cooperation among different offices. The DSO also cares about the proper processing of the official documents to meet the deadline and the expectation of the Ministry of Education and other governmental agencies. The DSO also devoted time and efforts to help the university president solve all sorts of problems on campus.

\section{G. Director of Research and Development Office}

The Dean of Research and Development Office (abbreviated as DRDO) cares most about how many research projects get funded and how much grant achieved from government or other agencies per year. DRDO also cares about the publications of faculty. How much articles were published in SCI or SSCI journals each year?

\section{HOW TO APPLY INFORMATION TECHNOLOGY TO SUPPORT UNIVERSITY ADMINISTRATORS TO MAKE DECISI ONS}

Part of the problems about applying information technology to support university administrators' decision making was due to the fact that university administrators 
usually used tactic knowledge to conduct management and administration. Tactic knowledge are usually viewed as hard to write down or codified by computer programs. However, Nonaka [3] proposed a model of organizational knowledge creation that differentiated tacit knowledge as uncodifiable knowledge (that can't be converted to be computer programs) and codifiable knowledge (that can be converted to be computer programs).

Some tactic knowledge of the university administrators can be codified by interviewing or being told or by observation [4]. If we can differentiate the codifiable tactic knowledge from the uncodifiable ones, and do the codifiable ones first, chances of success will be promising. We defined the codifiable tactic knowledge as some information that is needed by the university administrators in the seven offices and can be generated by grasping data from the current database. To help the university administrator in decision making, we felt a need to move from the current data-based WBA system to a new e-administration system to implement the codifiable tactic knowledge of administrators to support their decision making.

\section{A PROTOTYPE OF AN ANALYSIS-BASED E- ADMINISTRATION SYSTEM}

We took the Office of Academic Affairs as an example to demonstrate how to move from data-based (i.e. current WBA) to analysis-based e-administration system to support the Dean of the office of Academic Affairs (abbreviated as DOAA) to quickly grasp the key information for decision making.

The system schema of the proposed analysis-based system is illustrated in Fig. 1 that provided a framework for IT professionals to design the analysis-based eadministration system for the DOAA. The newly added functions beyond the current WBA system were shown in red color in Fig. 1.

\section{A. The SWOT Analysis of the Case Universitype of an Analysis-based E-administration System}

Based on the SWOT analysis shown in Fig. 1, the strengths, weakness, opportunities, and threats of the case university were stated as follows:

- Strengths: There are secure job markets and good pay for students graduated from some departments. Moreover, the tuition of the case university is lower than many other private universities due to the support from its conglomerate.

- Weakness: Firstly, the case university is locat eastern part of Taiwan that is not as convenient as those located in the western part of Taiwan. Secondly, the case university has some difficulty in recruiting enough senior professors because its retirement plan is not as attractive as that of the public university. Thirdly, the case university lacks systematic policy to recruit and retain good students, and the dropout rates are high in some departments.ed in the

- Opportunities: Growing elder population in Taiwan creates more demand in health care, and it will be helpful for recruiting students in the College of Medicine. Also, the Ministry of Education in Taiwan puts more efforts in promoting teaching excellence, and the case university had received some extra funding from the government in the past three years.

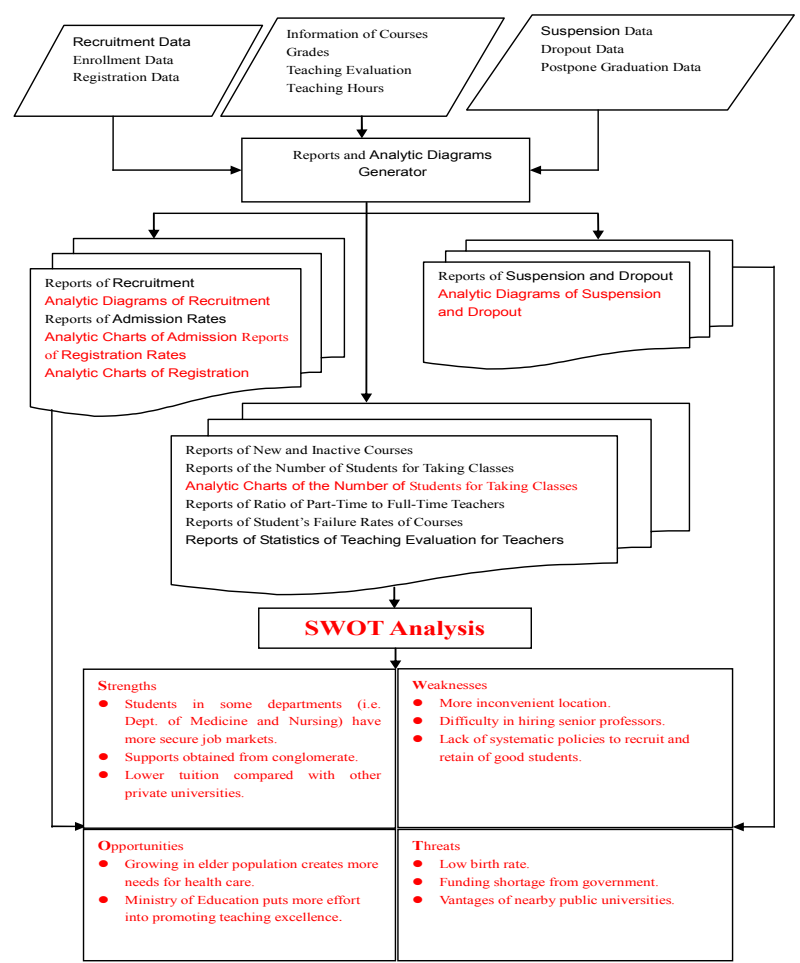

Figure 1. The system schema of SWOT analysis for Academic Affair Office.

- Threats: The lower birth rate in Taiwan in the past ten years creates more pressure of recruiting students in the future. Also, there is a nearby public university that had its vantages in terms of lower tuition, bigger campus and more senior professors. Moreover, due to the tight budget of Taiwanese government, the total amount of government funding to the case university has somehow decreased.

\section{B. The Comparison of Five Departments}

The SWOT analysis mentioned above revealed the strengths, weakness, opportunities and threats of the case university. However, different departments in the case university had their own uniqueness. We took five departments in a popular college to conduct comparisons and analysis as shown in Table I.

- The ranking of Department A in the entrance exam is the best among five departments, and only the very smart students can be admitted. Students who graduated from Department A get good job and earn very good pay although they usually need to work extra hours and rotation is usually required when they are junior on the job.

TABLE I: THE COMPARISONS OF THE FIVE DEPARTMENTS

\begin{tabular}{|c|c|c|c|c|}
\hline $\begin{array}{c}\text { Departme } \\
\text { nt Name }\end{array}$ & $\begin{array}{c}\text { Ranking } \\
\text { in the } \\
\text { entrance } \\
\text { exam }\end{array}$ & job market & Salary & $\begin{array}{c}\text { Worki } \\
\text { ng } \\
\text { hours } \\
/ \\
\text { rotatio } \\
n \\
\text { require } \\
\text { ment }\end{array}$ \\
\hline
\end{tabular}




\begin{tabular}{|c|c|c|c|c|}
\hline A & 1 & Very good & $\begin{array}{c}\text { Very } \\
\text { good }\end{array}$ & $\begin{array}{c}\text { Long/ } \\
\text { Yes }\end{array}$ \\
\hline B & 2 & Good & $\begin{array}{c}\text { above } \\
\text { average }\end{array}$ & $\begin{array}{c}\text { Normal } \\
\text { No }\end{array}$ \\
\hline C & 5 & Limited & Average & $\begin{array}{c}\text { Normal } \\
\text { No }\end{array}$ \\
\hline D & 3 & Good & $\begin{array}{c}\text { Above } \\
\text { average }\end{array}$ & $\begin{array}{c}\text { Long/ } \\
\text { Yes }\end{array}$ \\
\hline E & 4 & Good & Varied & $\begin{array}{c}\text { Normal } \\
\text { No }\end{array}$ \\
\hline
\end{tabular}

- The ranking of Department B in the entrance exam is the second among five departments, and it has an above average job market. Students graduated from Department B get above average pay once they obtained the national certificate, and they usually work normal hours with limited needs for rotation.

- The ranking of Department $\mathrm{C}$ in the entrance exam is the last among five departments, and it has limited job market. Students graduated from Department $\mathrm{C}$ get a lower than average pay unless they pass a very competitive national exam to be governmental officials. However, they can work in normal hours with no need for rotation.

- The ranking of Department D in the entrance exam is the third among five departments, and the demand in job market is high. Students graduated from Department D get an above average pay, but they have to work extra hours and the rotation of tasks are normally needed.

- The ranking of Department E in the entrance exam is the fourth among five departments. Students graduated from Department E get an average to high pay depending on what types of jobs they get, and the job market is also fairly good. They may need to work extra hours depending on the types of jobs, and the more experiences they got, the higher the pay.

\section{The Enrollment Rates among Five Departments}

The job market, future pay, future working hours and rotation requirement may influence new students' enrollment rate. Based on analysis of the enrollment rate from Year 2005 to Year 2010 (as shown in Fig. 2), Department A has highest enrollment rate (that fluctuated from $92 \%$ to $100 \%$ from Year 2005 to Year 2010) for the new students. It may be due to the fact that the future job market and pay are promising, but some excellent students retake the entrance exam next year with a hope to get better results. So, the enrollment rate is not always $100 \%$.

The enrollment rate in Department B fluctuates over time $(82 \%-92 \%)$. It is possible that the admitted students were quite competent academically, and some of them may retake the entrance exam next year to see if they can get better results. The enrollment rate in Department $\mathrm{C}$ is lowest $(80 \%$ - $87 \%$ ) among five departments, and it may be due to the limited job market. The future pay is also not as great as those who graduated from other departments in the same college. Department D has higher enrollment rate $(90 \%$ $98 \%$ ), and it may be due to the secure job market and above average pay in the future job, so many parents will encourage their children to select and enroll in Department D. The enrollment rate of Department $\mathrm{E}$ is pretty good $(87 \%$
- 94\%) because the job market and future pay are good. It seems that future job market and pay are two important factors that most parents concerned when they helped their children select department after entrance exam.

By seeing the change of enrollment rate from 2005 to 2010 shown in Fig. 2, the Dean of Academic Affairs (abbreviated as DOAA) could pinpoint that Department B and $\mathrm{C}$ needed more supports in recruiting students. The DOAA could discuss with the department heads of these two departments about how to present the superiority and potential job markets of their departments to inform and attract new students via social media or in University Fair.

\section{The Teaching Evaluation and Failure Rates among} Five Departments

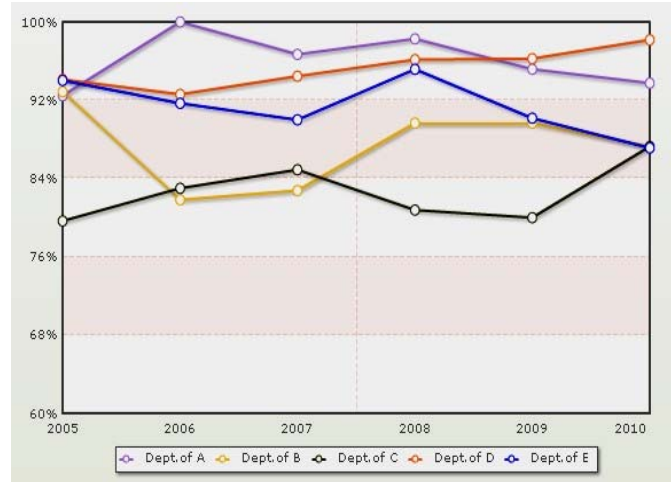

Figure 2. Enrollment rate among five departments from Year 2005 to 2010 .

Fig. 3 showed the teaching evaluation among five departments. Students in Department B (3.9 - 4.2 using a five point Likert scale), C (3.95 - 4.2), and D (4.05 - 4.25) gave better and more stable teaching evaluation to their instructors. It reflected that students in Department B, C and $\mathrm{D}$ are more satisfied with their professors' teaching. On the other hand, Department A (3.7 - 4.2) and Department E (3.65 - 4.15) gave lower teaching evaluation to their instructors and the teaching evaluation varied over six years.

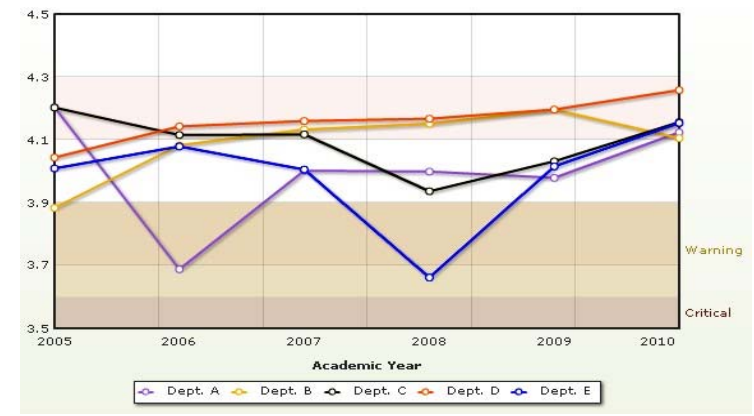

Figure 3. Teaching evaluation among five departments from Year 2005 to 2010 .

Fig. 4 shows the failure rate among five departments. Students in Department A (1\% - 2\%), B (4\%-5\%), C (4\% $8 \%)$, and D $(6 \%-9 \%)$ had relatively lower failure rate, whereas students in Department $\mathrm{E}$ had much higher failure rate $(13 \%-18 \%)$. Thus, the DOAA needed to investigate why students in Department $\mathrm{E}$ had higher failure rate and lower teaching evaluation. The DOAA could discuss with the department head and faculty members or to interview with some students of Department $\mathrm{E}$ to find out the reasons. Could it be the difficulty of the curriculum? Or, did the instructors have higher grading standards? Or, were students 
in Department E not satisfied with the instructors' teaching?

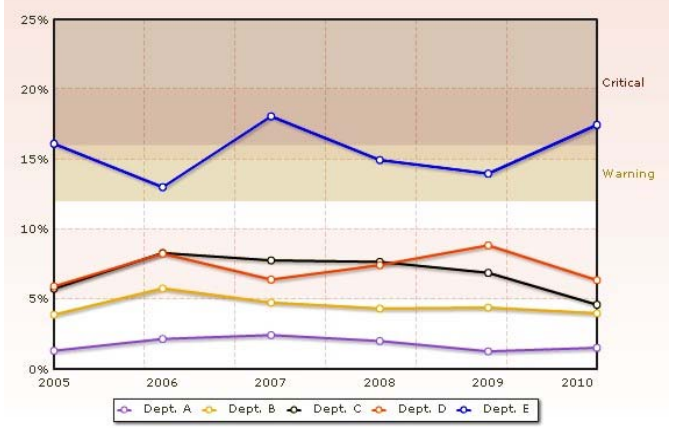

Figure 4. Failure rate among five departments from Year 2005 to 2010.

By identifying the problems, the DOAA could then come up with some strategies to solve the problems. For examples, if the faculty members whose teaching evaluations were among the last 5\%, then their teaching activities would be videotaped and given to teaching experts in the Division of Faculty Development Center to give advice in terms of improvement in teaching. Alternatively, the Office of Academic Affairs will send an alert message to the department head and faculty members regarding to some students who failed two required courses or three elective courses, and a free tutoring service would be given to those students.

The teaching evaluation of Department $\mathrm{A}$ is also lower than Department B, C, and D. The DOAA needed to find out why the smart students in Department A with lowest failure rate were not satisfied with the teaching performance of their professors. Did students satisfy with the curriculum, teaching strategies or activities? The DOAA needed to identify the problems and solve the problems consequently, so the smart students in Department A can be retained until graduation.

\section{E. The Registration / Drop Rates among Five}

Departments and Their Reasons for Dropout

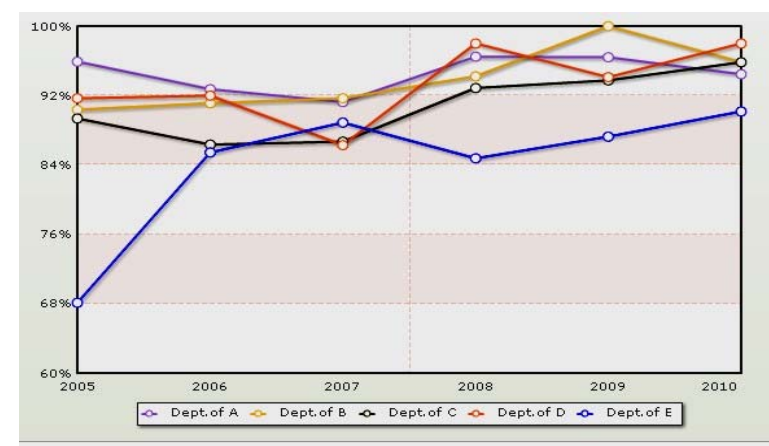

Figure 5. Registration rate among five departments from Year 2005 to 2010

Fig. 5 shows the registration rate (that is calculated as the number of students registered divided by the total numbers of eligible students in the whole department each year) of students among five departments. The most unstable one is Department E, and it fluctuated between 68\% in Year 2005 and $90 \%$ in Year 2010. However, it is in an upward direction year by year. On the other hand, the registration rates of Department A (92\% -95\%), Department B (90\% $100 \%)$, Department C (86\% -95\%), and Department D (86\% - 98\%) were more stable.

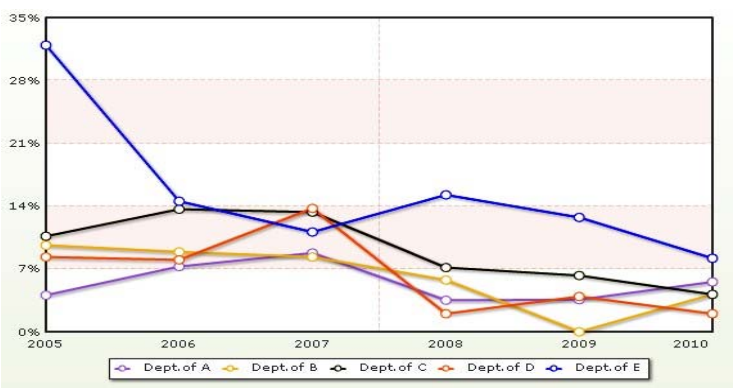

Figure 6. Dropout rate among five departments from Year 2005 to 2010 .

Fig. 6 shows the dropout rate (that is calculated as the number of students dropout divided by the total numbers of eligible students in the whole department each year) of students among five departments.

The reasons of dropout in Year 2010 were displayed in Fig. 7. Family issues (25\%), transfer to other universities $(25 \%)$, and lack of interest $(21.88 \%)$ were three major reasons. However, failure in grade $(6.25 \%)$, finance $(3.13 \%)$ and military obligations $(3.13 \%)$ were non-significant reasons.

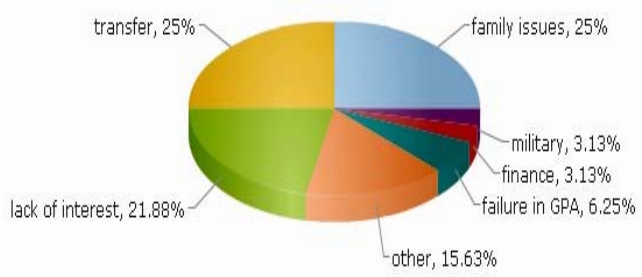

Figure 7. Dropout reasons among five departments in 2010

The evidences provided by Fig. 5, 6 and 7 inform the DOAA to take action in Year 2005 to stop the low registration rate and high dropout rate in Department E. The DOAA needed to identify the problem by discussion with department head, faculty members and interviews with students to understand the embedded problems and then solved the problems consequently. From then on, the registration rate goes up in Department E.

\section{F. The Graduation Rates among Five Departments}

Fig. 8 shows the graduation rates of students among five departments. Department A is the highest (92\% - 98\%). Department B is the second $(91 \%-100 \%)$. Department C $(77 \%$ - 90\%) and Department D (74\% - 93\%) were quite stable, but they both had sudden drops in Year 2010. Department E (66\% - 84\%) was lowest.

Based on information shown in Fig. 8, the DOAA had to find out why the graduation rate was low in Department $E$ in Year 2006, 2008 and 2009, and why the graduation rate of Department C and D suddenly drop in Year 2010The lower graduation rate or delay in graduation can be caused by many different reasons. For examples, some students may take extra courses or double majors or prepare to go to graduate school after graduation, so they decided to postpone their graduation by leaving one or two courses untaken to study one more year. It is important for the DOAA to pinpoint the problems and solve problems. It is critical to show the good wills of school administration to help students graduate and get the degree they pursued because students had paid so much tuition and had spent so 
much time in the university.

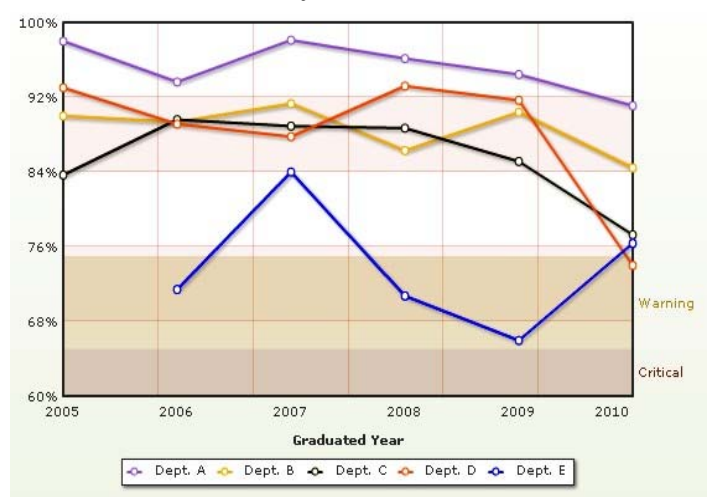

Figure8. Graduation rate among five departments from Year 2005 to 2010.

\section{CONCLUSIONS AND EDUCATIONAL IMPLICATION}

The e-administration has evolved from PC-based to the current WBA system, and it greatly reduced labor, cost and time for running administration in the higher education. However, the current WBA did not focus on supporting the needs of university administrators. This paper suggested information needed in the seven offices in the case university for administrators to make decisions and suggested a direction for the evolution of the current WBA system. We picked up the Office of Academic Affair as an example to illustrate our ideas about moving from databased to analysis-based e-administration system. We chose five departments in a popular college to show how the critical information (such as students' enrollment rate, teaching evaluation, failure rate, registration rate, dropout rate and graduation rates) can provide meaningful information and signals for the DOAA to take necessary actions to solve the problems encountered.

By moving from data-based e-administration system to analysis-based e-administration system, we not only change the information flow from paper-format to electronic format with objectives to save time, cost and labor, but also support the decision making of the administrators in the higher education. The graphs of the critical information (that DOAA cares about) over six-year periods show the longterm trends and variations, and also reveal the problems embedded in different departments that required attentions to rectify. The analysis-based e-administration system helps university administrators understand the long-term performance of different departments in the university, identify problems before they get worse, and hence it may promote the administrative efficiency more effectively.

\section{REFERENCES}

[1] P. Y. Chu, and Z. L. Wang, "An empirical study of the current status of e-administration among five universities: the analysis of computer competence and attitude of administrative staff". Chinese Management Review, 3(2), 2000, pp. 135-150.

[2] J. Koester, "Information Technology and Tomorrow's University: A President's Confessions and Advice," EDUCAUSE Review, vol. 46, no. 1, January/February 2011, pp. 34-43.

[3] I. Nonaka, and G. von Krogh, "Perspective-tacit knowledge and knowledge conversion: Controversy and advancement in organizational knowledge creation theory". Organization Science, vol. 20, no. 3, 2009, pp 635-652.

[4] K. Parsaye, and M. Chignell, "Expert systems for experts", Hoboken, NJ: Wiley, pp. 365, 1988, ISBN 9780471601753. 